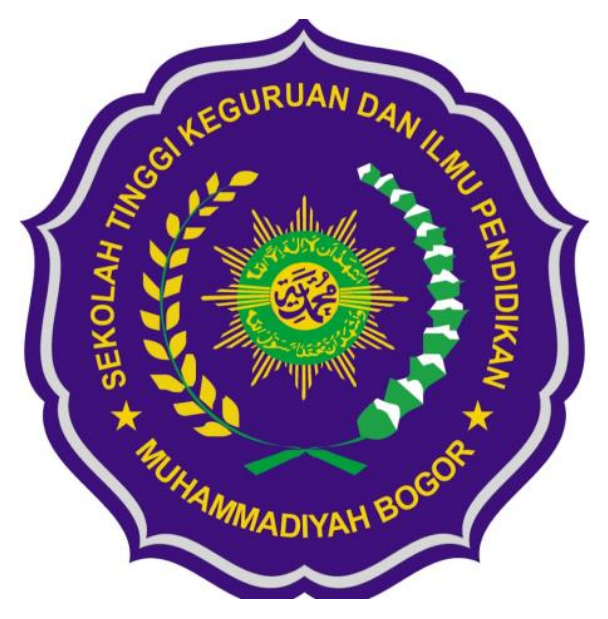

PROGRAM STUDI PENDIDIKAN GURU PAUD

STKIP MUHAMMADIYAH BOGOR

BOGOR

2019 


\section{MENGANALISIS PERMASALAHAN DI PAUD BINA MULIA}

Masalah adalah sebuah tindakan yang terjadi secara reflex tanpa di rencanakan,yaitu sebuah ekspresi emosi anak yang akan mengganggu kehidupan anak, timbul karena ketidaksesuaian pada perkembangannya. ,Masa Egosentrisme yang menyebabkan timbulnya permasalahan anak usia dini oleh sebab itu perlu adanya pemecahan masalah agar permasalahan dapat di atasi sejak dini. Berikut ini permasalahan anak usia dini yang ada di PAUD BINA MULIA:

1).Permasalahan yang pertama yaitu, Ananda......mempunyai permasalahan di sekolah sebagai anak yang tidak mau bersabar ketika menginginkan sesuatu,apabila tidak di ikuti maka ananda akan menangis Tantrum atau menangis secara berlebihan,bahkan semua benda yang ada di dalam maupun di luar kelas,maka ananda tidak segan lagi untuk melempar semua benda sampai semua keinginannya terpenuhi baru akan mereda semua emosinya,dan terkadang temannyapun akan menjadi sasarannya,contohnya yang sering di lakukan yaitu tidak mau berbagi mainan dengan temannya serta selalu menguasai semua mainan di sekolah,sudah 2 tahun bersekolah baru ada perubahan di semester 2 yaitu mulai mau bersosialisasi tetapi sikap egosentrisme dan menangis tantrumnya masih belum ada perubahan.

Tindakan pemecahan masalah,yang di lakukan oleh kami pertama kami berusaha membujuk dengan lemah lembut serta memberikan pengertian dan pengarahan bahwa sifat seperti itu tidak baik di lakukan,contohnya "ananda anak yang sholihah dan pintar baik hati mainannya boleh bergantian ya....nanti ananda boleh memainkan mainan yang lain,ananda baik deh nanti banyak yang sayang, di sayang Allah dan juga teman". Tetapi dengan cara membujuk kami belum berhasil,kemudian kami menggunakan cara yang ke 2 yaitu,melakukan visit ke Rumah ananda melakukan Tanya jawab tentang riwayat ananda,Alhamdulillah pihak keluarga terbuka pada kami dan mau menceritakan,ananda adalah salah satu korban perceraiain yang kurang kasih sayang dari ibunya karna yang 
merawat ananda hanya neneknya, sementara sang ayah harus mencari nafkah dan dari kecil sudah tidak di rawat lagi oleh ibunya,ayah beserta nenek selalu mengikuti keinginan ananda apapun itu dan hasilnya ananda tumbuh menjadi anak yang Berkemauan keras (keras kepala).kami berusaha mencari solusi dan pemecahannya serta memberikan pengarahan kepada keluarga untuk selalu tidak mengikuti keinginannya,saya hanya berusaha dengan semaksimal mungkin sampai akhirnya sekarang sudah lulus dan sekolah di SD,kami seorang Guru tentunya sangat sedih dengan kejadian ini,kami merasa Belum berhasil memang tidak mudah membimbing anak yang sudah karakternya terbentuk menjadi Berkemauan keras(keras kepala),tetapi kami masih tetap berkomunikasi baik dengan keluarga dan juga ananda serta memantau ananda ,kami berharap agar ada perubahan dari sikap serta ahlak ananda.

2).Permasalahan yang kedua yaitu ananda mempunyai gangguan konsentrasi serta sikap yang tidak mau bersosialisasi dan tidak mau berkomunikasi dengan guru maupun temannya,ketika datang kesekolah ananda hanya berdiri di samping pintu walaupun di sambut sama kami ananda tetap diam dengan posisi berdiri dan tidak mau melepaskan tasnya,setelah kami membujuk berulang - ulang baru ananda merespon mau duduk serta melepaskan tasnya,setelah itu ananda akan kembali diam dengan tatapan mata kosong melihat aktifitas teman - temannya,ananda selalu ingin di perhatikan dengan khusus jika kami tidak memperhatikannya ananda akan diam di dalam kelas tidak akan melakukan apapun,ananda juga kurang paham dengan ucapan perintah dua kalimat sederhana,seperti: ananda tolong tangkap dan lempar bola,yang ananda lakukan hanya satu kaliamat saja maka ananda akan melakukan menangkapnya saja,ananda juga belum bisa menjawab pertanyaan kalimat sederhana,seperti ananda berangkat sekolah di antar siapa? Ananda tidak langsung menjawab atau merespon ananda akan diam tidak menjawab 
setelah kami bertanya berulang - ulang baru ananda akan merespon dan menjawabnya.

\section{Pemecahan masalah}

Tindakan dan solusi yang kami lakukan yaitu dengan cara menstimulus melalui melatih konsentrasi melalui sering di ajak berkomunikasi dan mengajak bergabung dengan teman - temannya yang sedang bermain,serta melakukan visitt kerumahnya,tetapi ketika kami akan melakukan visit kerumahnya ibu ananda melarang kami untuk kerumahnya dengan alasan beliau takut di marahi sama ayah ananda,dan akhirnya beliau mau menjelaskan dan menceritakan kondisi keluarga beliau yang kurang harmonis,dan ayah ananda sering melarang ananda ketika berada di rumah,seperti melarang bermain di luar,ketika melarang ananda dengan cara memarahi,akhirnya kami mengetahui penyebabnya dan kami terus mencoba menstimulus dengan sering berkomunikasi dan mengajak bermain bersama temannya dan Alhamdulillah sedikit demi sedikit sudah mulai ada perubahan,sebelumnya ibu ananda mau mnyekolahkan satu tahun saja tetapi kami meminta kepada ibu ananda untuk tidak melanjutkan ke SD dulu dan tetap sekolah di PAUD satu tahun lagi karna kami mengkhawatirkan ananda yang belum bisa bersosialisasi kurang konsentrasi,Alhamdulillah beliau mau menerima permintaan kami dan akhirnya perubahan sedikit demi sedikit sudah mulai terlihat,seperti ananda sudah mau bergabung dengan temannya serta sudah mulai merespon pertanyaan dari guru ataupun temannya.

Kesimpulan:Anak yang terlahir ke Dunia itu semuanya cerdas pintar serta unik,memiliki kelebihan serta memiliki perkembangan yang berbeda,tergantung bagaimana cara kita mendidiknya,Anak bisa di bentuk sesuai dengan apa yang kita inginkan karna anak belajar dari kehidupannya 
Jika anak dibesarkan dengan celaan,ia belajar memaki

Jika anak dibesarkan dengan permusuhan,ia belajar berkelahi

Jika anak dibesarkan dengan cemoohan,ia belajar rendah diri

Jika anak dibesarkan dengan penghinaan,ia belajar menyesali diri

Jika anak dibesarkan dengan toleransi,ia belajar menahan diri

Jika anak dibesarkan dengan dorongan,ia belajar percaya diri

Jika anak dibesarkan dengan pujian,ia belajar menghargai

Jika anak dibesarkan dengan sebaik-baiknya perlakuan,ia belajar keadilan

Jika anak dibesarkan dengan rasa aman,ia beajar menaruh kepercayaan

Jika anak dibesarkan dengan dukungan,ia belajar menyenangi dirinya

Jika anak dibesarkan dengan kasih sayang dan persahabatan,ia belajar menemukan cinta dalam kehidupan.

Apabila manusia telah meninggal,terputuslah amal perbuatannya,kecuali

tiga hal,yaitu: amal jariyah,ilmu yg bermanfaat dan anak yg sholeh yg selalu mendoakannya." <Diriwayatkan oleh Muslim dari Abu Hurairoh> Untuk itu sayangilah putra dan putri Bunda dan Yanda agar Putra dan Putri kita menjadi anak yang shalih dan salihah yang berakhlak mulia dan membanggakan orang tua. 


\section{DAFTAR PUSTKA}

Sugiri, Sugiri \& Sulfemi, Wahyu Bagja. (2011). Pendidikan Multi Kultur di Sekolah Berbasis Keagamaan. Edutecno. 3 (2), 11-20

Sulfemi, Wahyu Bagja. (2015). Kemampuan Pedagogik Guru. Prosiding Seminar Nasional. STKIP Muhammadiyah Bogor 1. (1). 71-83

Sulfemi, Wahyu Bagja. (2019). Manajemen Pendidikan Multi Kultur. Bogor : STKIP Muhammadiyah Bogor.

Sulfemi, Wahyu Bagja dan Mayasari, Nova. (2019). The Use of Audio Visual Media in Value Clarification Technique to Improvestudent Learning Outcomesin Social Studies. Jurnal Pendidikan. 20 (1), 53-68. 